\title{
A volcanically triggered regime shift in the subpolar North Atlantic Ocean as a possible origin of the Little Ice Age
}

\author{
C. F. Schleussner ${ }^{1,2}$ and G. Feulner ${ }^{1}$ \\ ${ }^{1}$ Potsdam Institute for Climate Impact Research, Telegrafenberg A62, 14473 Potsdam, Germany \\ ${ }^{2}$ Physics Institute, Potsdam University, Potsdam, Germany \\ Correspondence to: C. F. Schleussner (schleussner@pik-potsdam.de)
}

Received: 27 November 2012 - Published in Clim. Past Discuss.: 18 December 2012

Revised: 16 May 2013 - Accepted: 27 May 2013 - Published: 25 June 2013

\begin{abstract}
Among the climatological events of the last millennium, the Northern Hemisphere Medieval Climate Anomaly succeeded by the Little Ice Age are of exceptional importance. The origin of these regional climate anomalies remains a subject of debate and besides external influences like solar and volcanic activity, internal dynamics of the climate system might have also played a dominant role. Here, we present transient last millennium simulations of the fully coupled model of intermediate complexity Climber $3 \alpha$ forced with stochastically reconstructed wind-stress fields. Our results indicate that short-lived volcanic eruptions might have triggered a cascade of sea ice-ocean feedbacks in the North Atlantic, ultimately leading to a persistent regime shift in the ocean circulation. We find that an increase in the Nordic Sea sea-ice extent on decadal timescales as a consequence of major volcanic eruptions in our model leads to a spin-up of the subpolar gyre and a weakened Atlantic meridional overturning circulation, eventually causing a persistent, basin-wide cooling. These results highlight the importance of regional climate feedbacks such as a regime shift in the subpolar gyre circulation for understanding the dynamics of past and future climate.
\end{abstract}

\section{Introduction}

The so-called Little Ice Age (LIA), a period of cool temperatures over the Northern Hemisphere, is among the most debated climatological events of the Holocene. Tree-ring reconstructions from central Europe reveal a reduction in summer temperature of $1 \mathrm{~K}$ and more (Büntgen et al., 2011) and the successive agro-ecological and socioeconomic downturn might have set the field for the outbreak of the "Thirty Years' War", one of the most destructive episodes in pre-industrial Europe (Zhang et al., 2011a). Even though the term Little Ice Age is widely used in the literature, a coherent definition did not emerge due to a substantial variance in the climate signal between different geographical regions and records. Jones and Mann (2004) define it as a period from 1300 $1450 \mathrm{AD}$ to $1850-1900$ including several warmer and colder episodes. Since the LIA coincides with a series of minima in sunspot activity, it has been interpreted as an example of the importance of multi-decadal variations in the total solar irradiance (TSI) to the earth's climate (Eddy, 1976), a hypothesis investigated in a range of model simulations of the last millennium (e.g., Crowley, 2000; Zorita et al., 2004; Swingedouw et al., 2012). Recent TSI reconstructions, however, estimate the changes in the radiative forcing over the last millennium to be of the order of $0.2-0.7 \mathrm{~W} \mathrm{~m}^{-2}$ as compared to the 2008/2009 solar minimum with a tendency towards the lower end (Jansen et al., 2007; Gray et al., 2010). In a modeling study, these low estimates have been shown to yield results that are consistent with Northern Hemisphere temperature reconstructions (Feulner, 2011). In these simulations, LIA cooling is dominated by the effect of volcanic eruptions, an alternative hypothesis that was suggested earlier (Robock, 1979; Crowley, 2000). Other models, however, cannot reproduce the magnitude of the MCA-LIA transition (Eby et al., 2013; Fernández-Donado et al., 2013), indicating a possible contribution of internal climate variability to the observed cooling. Internal variability of the climate system can lead to pronounced climate anomalies, though model simulations suggest that long-term anomalies like the LIA cannot be sustained without external forcing (Hunt, 2006). 
Goosse et al. (2012a) found a coupled atmosphere-ocean circulation regime shift between MCA and LIA in the LOVECLIM model.

Reconstructions suggest a slowing down of the Atlantic meridional overturning circulation (AMOC) during the LIA (e.g., Broecker, 2000; Lund et al., 2006) and model results indicate a multi-decadal to centennial internal variability of the AMOC (Menary et al., 2011). North Atlantic sea surface temperatures exhibit a periodic signal, the Atlantic multidecadal oscillation (AMO), on timescales of $50-70 \mathrm{yr}$ in observational records (Schlesinger and Ramankutty, 1994; Parker et al., 2007) as well as in paleo-reconstructions over the last $8000 \mathrm{yr}$ (Knudsen et al., 2011). This oscillation is found to be closely coupled to AMOC dynamics in coupled general circulation models (Knight et al., 2005; Pohlmann et al., 2009). Park and Latif (2011) report several modes of AMOC variability in the KCM coupled general circulation model with a multi-decadal mode that dominates in the North Atlantic and a quasi-centennial mode that is found to originate in the Southern ocean. Wind-driven mixing in the Southern ocean is a key driver of the overturning system (Kuhlbrodt et al., 2007), and variable wind forcing might contribute significantly to AMOC variability (Hunt, 2011).

Concerning possible external drivers of AMOC changes, Otterå et al. (2010) presented model results indicating that volcanic eruptions, despite the short lifetime of their atmospheric imprint, may be an important driver of multidecadal AMOC variability. The climatic impact of volcanic eruptions comprises dynamic responses of a variety of internal modes of the global climate system (e.g., Robock, 2000; Timmreck, 2012) that can persist on multi-decadal timescales (Zanchettin et al., 2011).

Decadally-paced volcanic forcing has been reported to result in persistent changes in North Atlantic climate on centennial timescales (Zhong et al., 2010). In contrast, other studies find little imprint of volcanic eruptions on the AMOC (Ortega et al., 2011; Hofer et al., 2011) or report a diverse set of responses over the last millennium (Mignot et al., 2011). In a model intercomparison, even more contradictory findings between different models and reconstructions are reported making the question of the origins of the LIA puzzling (Fernández-Donado et al., 2013). Ensemble simulations with models of intermediate complexity indicate the importance of internal and regional climate variability when identifying the systems response to external forcing (Goosse et al., 2005, 2012b).

Considering changes in the atmospheric dynamics, the North Atlantic Oscillation (NAO) is the leading atmospheric mode of North Atlantic climate variability (Hurrell and Deser, 2009). Reconstructions suggest that the MCA was characterized by a persistent positive NAO (Trouet et al., 2009; Olsen et al., 2012), followed by a transition into a more variable state including strongly negative episodes during the LIA. Model results and observations indicate that those strong negative NAO episodes might have contributed significantly to winter cooling in northern and central Europe (Gouirand et al., 2006). Besides other reconstruction that lag a prominent MCA-LIA transition in the NAO index (Cook et al., 2002), multi-ensemble studies with complex coupled climate models also fail to reproduce a persistent NAO strong state during the MCA (Lehner et al., 2012).

An increase in sea-ice extent was found in the western Nordic seas, interrupted by short periods of greatly reduced ice cover (Macias Fauria et al., 2009). Reconstructions for the whole Arctic ocean even suggest an overall decrease in sea-ice extent over the LIA (Kinnard et al., 2011), again illustrating the irregular spatial pattern of climate anomalies during this episode and highlighting the importance of regional climate feedbacks.

Here, we present a systematic approach to separate the impacts of changes in TSI, volcanism, greenhouse gas emissions and reconstructed wind-stress variability on the North Atlantic Ocean during the last millennium. We compare our outcome to multi-proxy reconstructions and suggest a mechanism for the MCA-LIA transition.

\section{Model and experiments}

\subsection{Model description}

The simulations presented in this study where performed with the intermediate-complexity climate model CLIMBER$3 \alpha$ (Montoya et al., 2005). Its oceanic component is based on the GFDL MOM-3 code (Pacanowski and Griffies, 1999), with 24 variably spaced vertical levels, a coarse horizontal resolution of $3.75^{\circ}$, a background vertical diffusivity of $\kappa_{\mathrm{h}}=0.3 \times 10^{-4} \mathrm{~m}^{2} \mathrm{~s}^{-1}$ and an eddy-induced tracer advection with a thickness diffusion coefficient of $\kappa_{\mathrm{gm}}=250 \mathrm{~m}^{2} \mathrm{~s}^{-1}$. It contains a coarse resolution statistical dynamical atmosphere (Petoukhov et al., 2000) and a thermodynamic/dynamic seaice component (Fichefet and Maqueda, 1997).

CLIMBER- $3 \alpha$ was found to reproduce large-scale characteristics of the global climate system. On the regional scale, the coarse model resolution and the simplified atmosphere limit its capabilities. For a comprehensive discussion of the model performance and comparison with observational data see Montoya et al. (2005).

Due to the coarse resolution, the SPG circulation does not extend into the Labrador Sea and therefore subpolar convection is limited to the central Irminger basin. The overflows over the Denmark strait are too strong resulting in an overestimated ice export by the East Greenland Current. Winter sea-ice extent over the Labrador Sea is found to exceed observations.

The area of deep convection in the Greenland Basin compares well with observations of mixed layer depth (de Boyer Montégut et al., 2004). CLIMBER-3 $\alpha$ was used in a variety of model intercomparison studies on the last 
millennium (Jansen et al., 2007; Eby et al., 2013) and on AMOC stability (Gregory et al., 2005; Stouffer et al., 2006).

\subsection{Experiment design}

In our modeling study of the last-millennium, the TSI reconstruction by Steinhilber et al. (2009) is applied, supplemented by the record by Wang et al. (2008) from 1850 onwards as recommended by the Paleoclimate Modeling Intercomparison Project (PMIP3). This reconstructed time series has been shown to yield hemispheric temperatures in CLIMBER-3 $\alpha$ close to ensemble reconstructions over the last millennium (Feulner, 2011).

For the volcanic forcing, the time series by Crowley (2000) is used and anthropogenic aerosols and greenhouse gas forcings follow the PMIP3 recommendations (Schmidt et al., 2011). The time series for the TSI only and the combined short-wave forcing is shown in Fig. 1a. Aerosol forcing is only considered in its direct impact on the TSI, since our atmospheric component lacks a sufficient representation of other climate impacts of aerosol release.

Since our statistical-dynamical atmosphere does not produce internal variability, we externally prescribed windstress by a stochastic construction method utilizing the 1049 to 1995 winter NAO reconstruction index by Trouet et al. (2009) and the annual surface wind-stress anomalies from the National Centers for Atmospheric Prediction (NCEP) and National Center for Atmospheric Research (NCAR) reanalysis data from 1948 to 2009 (Kalnay et al., 1996). A similar, though non-stochastic approach is presented in Sedláček and Mysak (2009) with the UVic model and based on the NAO reconstruction by Luterbacher et al. (2002) for the period from $1500 \mathrm{AD}$ onwards. In a first step, we derived the standard deviation of the winter NAO index as provided by Hurrel (2012) giving a standard deviation of 1 for the period 1899 to 2012. Assuming that the distribution provides a statistically independent probability for the index of a mean state, it allows us to construct wind-stress time series for the entire 1049 to 1995 period. For each year in the Trouet et al. (2009) time series, the index is set as the mean of a normal distribution with the derived standard deviation. This distribution is taken as the probability distribution to sample years out of the NCEP 1948 to 2009 period using inverse transform sampling. One resulting time series is exemplarily shown in the lower panel of Fig. 1 in comparison with the reconstructions by Trouet et al. (2009).

It is unlikely that North Atlantic wind-fields over the last millennium with greatly varying regional climate conditions will be sufficiently represented by a construction procedure based on a $60 \mathrm{yr}$ time series. In particular, for the reconstructed persistent positive NAO-phase during the MCA, this method leads to weaker NAO reconstructions due to the lack of particular high NAO years in the time series. Our purely statistical method is not capable to capture the physical processes behind NAO variations. The comparison of

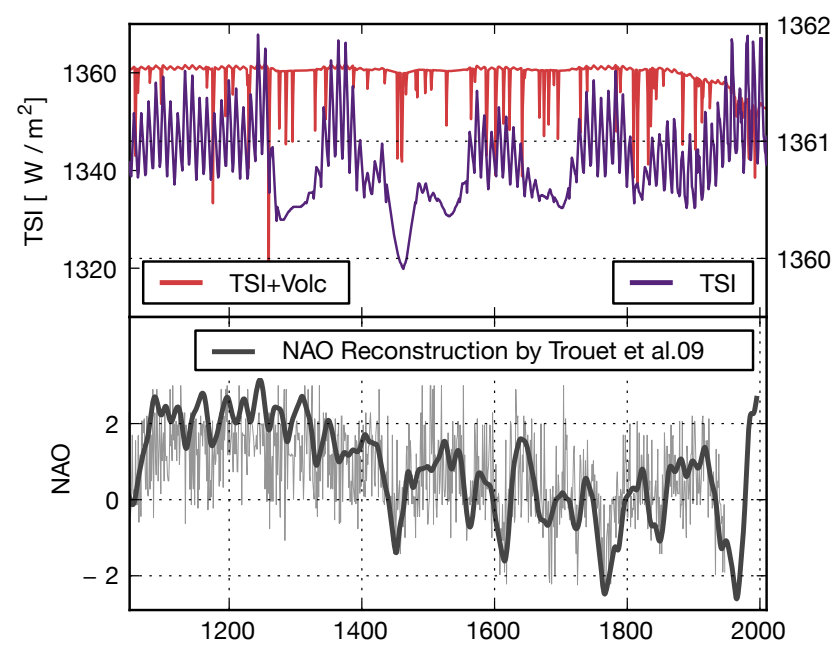

Fig. 1. Externally prescribed forcing time series as applied in our simulations. Upper panel: the TSI forcing time series by Steinhilber et al. (2009) (purple) and the full top-of-the-atmosphere short-wave TSI forcing including aerosols from volcanic eruptions and anthropogenic emission (red). Lower panel: based on NAO reconstructions by Trouet et al. (2009) and NCEP/NCAR reanalysis data, wind-stress patterns were stochastically constructed as described in Sect. 2. Out of ten ensemble members, one NAO time series is shown in light grey for comparison.

an ensemble constructed using this stochastic procedure can however yield interesting insights into how the atmospheric component influences North Atlantic Oceanic variability. An ensemble of 10 stochastic wind-stress time series is created and all experiments are performed for all ensemble members. These wind-stress time series are added to a prescribed climatology (Trenberth et al., 1989). From 1948 onwards, the anomalies according to the NCEP reconstruction are applied for all ensemble members.

Subpolar oceanic resonance to atmospheric forcing in our model is enhanced to reproduce observed variability when a constant freshwater forcing offset is applied over the convective region in the Nordic seas $\left(63.75-78.75^{\circ} \mathrm{N}\right.$ and $11.25^{\circ} \mathrm{W}-10^{\circ} \mathrm{E}$ ) as shown in Mengel et al. (2012). The offset applied in their model study is $15 \mathrm{mSv}$ and thereby within the range of natural variability as estimated by Curry and Mauritzen (2005) for the second half of the 20th century. In the model results presented here, no freshwater offset is applied. But to test the sensitivity hypothesis, we additionally performed ensemble simulations with a small freshwater offset of $5 \mathrm{mSv}$ in the Nordic seas.

All runs were started from an equilibrium simulation with a constant $\mathrm{CO}_{2}$ concentration of $277 \mathrm{ppm}$ and a solar constant of $1361 \mathrm{~W} \mathrm{~m}^{-2}$ according to Kopp and Lean (2011), which was spun-up over $200 \mathrm{yr}$ starting in the year 850 . For the $5 \mathrm{mSv}$ experiment, the constant freshwater offset is applied. 
During spin-up, the applied wind-stress anomalies are based on the NCEP/NCAR 1948-2009 wind-stress time series. To avoid discontinuities the 1948-2009 period is combined with reversed 2009-1948 time series (Mengel et al., 2012). The resulting $122 \mathrm{yr}$ time series is cyclic and continuously applied during spin-up. The volcanic forcing mirrored from the years 1000-1150 was applied for the 8501000 period.

\section{Results}

As depicted in Fig. 2b, the ensemble mean without a freshwater offset exhibits a persistent switch in the circulation regime of the subpolar gyre (SPG) during the late 17th century with a large spread for the different stochastic windstress forcing reconstructions. The regime shift in the SPG circulation is the result of a cascade of self-amplifying feedbacks as discussed in Levermann and Born (2007) and Mengel et al. (2012). A stronger SPG entrains more saline North Atlantic Current (NAC) waters in the subpolar region thus strengthening subpolar convection. Increased subpolar convection leads to a cooling and densification of the SPG center and thereby to a baroclinic intensification of the SPG. Due to increased NAC entrainment, the overflows over the Greenland-Scotland Ridge (GSR) are reduced and the impact of this regional regime shift on the AMOC is negative. In equilibrium, the AMOC at $30 \mathrm{~N}$ is found to be about $6.5 \%$ weaker in the strong compared to the SPG weak regime in our model (Mengel et al., 2012).

In the simulations presented here, the SPG regime shift is accompanied by a transient AMOC reduction of about $5 \%$ between MCA and LIA and an increase in sea ice over the Nordic seas (North Atlantic Sea-Ice Extent (NASIE), $40^{\circ} \mathrm{W}-$ $20^{\circ} \mathrm{E}, 64^{\circ} \mathrm{N}-80^{\circ} \mathrm{N}$; see Fig. 2a) that is consistent with seaice reconstructions by Macias Fauria et al. (2009).

A multi-stable SPG circulation regime has been reported for a variety of climate models (Born et al., 2013; Schulz et al., 2007) and SPG variability has been found to dominate the multi-decadal AMOC variability signal in various model studies (e.g., Msadek and Frankignoul, 2009; Park and Latif, 2011). The SPG spin-up exhibits a threshold behavior in our model (Mengel et al., 2012) and is very sensitive to small changes in the western Nordic seas freshwater budget and atmospheric variability. We conducted the same model ensemble simulations with an additional freshwater offset in the Nordic seas of $5 \mathrm{mSv}$ (blue, as described above) and found a switch in the ensemble mean around 1450 in line with the onset time of the LIA in most climate records. When comparing model ensemble results with an AMO reconstruction index by Mann et al. (2009), we find better agreement between the $5 \mathrm{mSv}$ offset ensemble and the reconstructions in the 16th and 17th century (Fig. 2d).

The actual timing of the transition should not be overinterpreted, since its very sensitive to minor changes in the

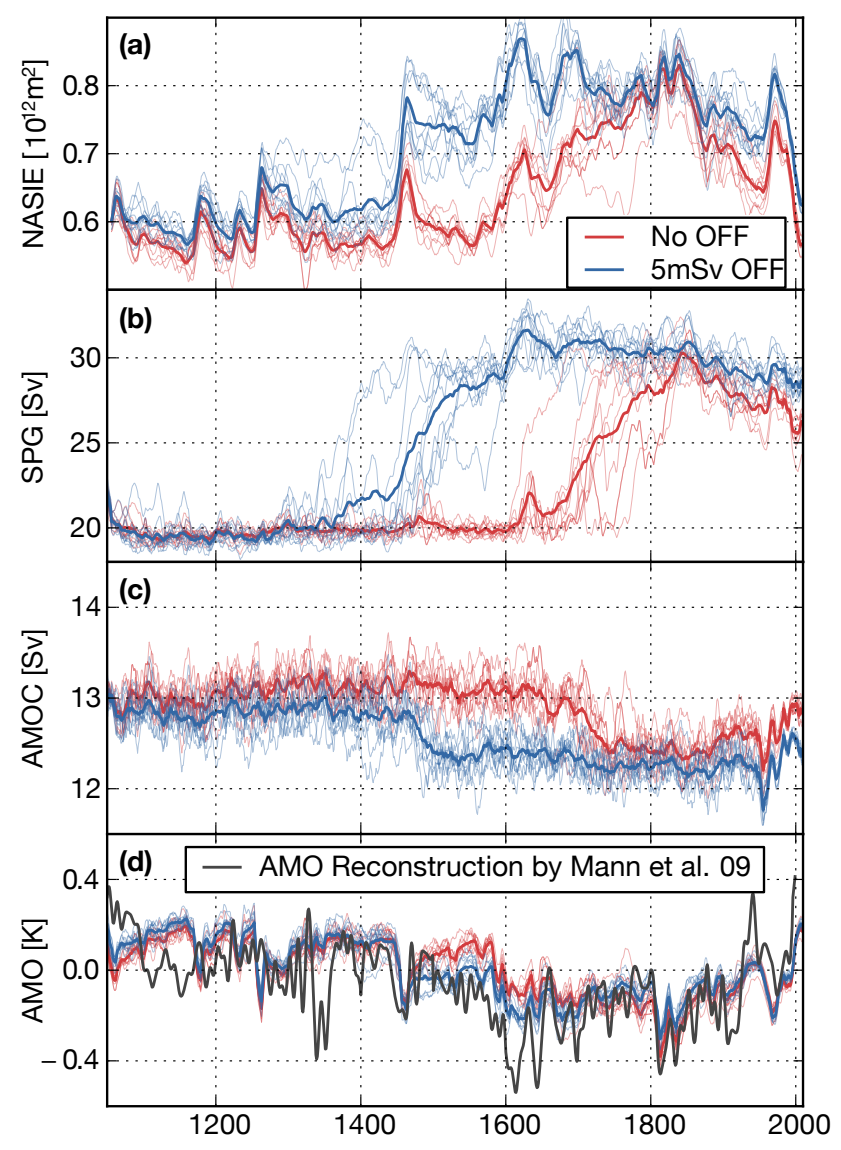

Fig. 2. Transient model results of the last millennium with prescribed TSI, $\mathrm{CO}_{2}$ and wind-stress forcing applied. (a) The North Atlantic Sea-Ice Extent (NASIE) for an ensemble with an additional $5 \mathrm{mSv}$ freshwater offset in the Nordic seas (blue) and without freshwater offset (red, individual ensemble members in light red, thick lines: ensemble mean). (b) Depicts the SPG dynamics and (c) the AMOC at $30 \mathrm{~N}$. (d) AMO anomalies in comparison with the reconstructed AMO index by Mann et al. (2009).

North Atlantic freshwater budget and also exhibits a considerable ensemble spread (compare Fig. 2). Yet, our results indicate that a transition in the SPG circulation regime might have been triggered during the onset of the LIA.

To identify the driving processes behind this basin-wide circulation shift, we decomposed the external forcings for all reconstructed wind-stress time series (Fig. 3) without additional freshwater offset. Again, great variations between the ensemble members are found, indicating the importance of atmospheric forcing on North Atlantic Ocean dynamics.

Paleo-reconstructions as well as GCM studies suggest a positive NAO state as a dynamical impact of tropical volcanic eruptions possibly leading to a European winter warming (e.g., Stenchikov et al., 1998; Kirchner et al., 1999; Shindell, 2004; Fischer et al., 2007). Within methodological limitations, the NAO reconstruction by Trouet et al. (2009) thus incorporates effects of volcanic eruptions and changes in the 

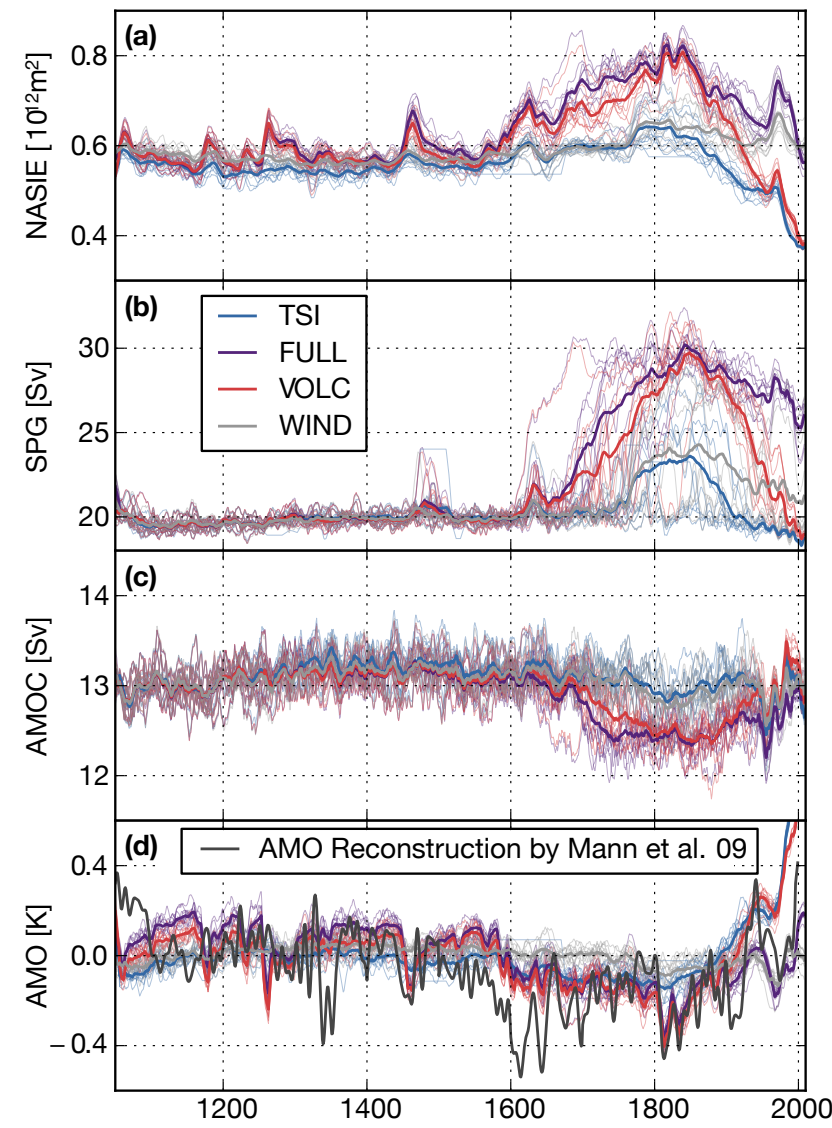

Fig. 3. To identify the driving processes behind SPG and AMOC dynamics, the different forcings applied are treated separately (bold: ensemble mean, light: individual members). Pure prescribed wind forcing (WIND) is shown in grey, wind plus changes in the solar irradiance only (TSI) in blue, wind plus volcanic forcing in red (VOLC) and the combination of all forcings (FULL) in purple. Anthropogenic $\mathrm{CO}_{2}$ is applied in TSI, VOLC and FULL. (a) NASIE, (b) SPG, (c) AMOC and (d) AMO anomalies in comparison with the reconstruction time series by Mann et al. (2009).

total solar irradiance. Restricted by our statistical approach as discussed above, these imprints are also present in our reconstructed wind-stress time series.

In our modeling study, wind-stress forcing alone (WIND, grey curve) did not lead to a full spin-up of the SPG and corresponding AMOC reduction during the LIA, but only resulted in a moderate signal in the 18th century. When compared to the reference AMO signal (Fig. 3d), atmospheric forcing alone also lacks some prominent features of the reconstruction, most importantly the cooling during the LIA. This picture does not change much, if TSI plus anthropogenic $\mathrm{CO}_{2}$ changes are applied (blue curve), ruling out changes of the TSI as the major origin of LIA cooling of the North Atlantic in our model experiments. These conclusions are, however, based on the TSI reconstruction applied; the result may look different for TSI reconstructions showing larger

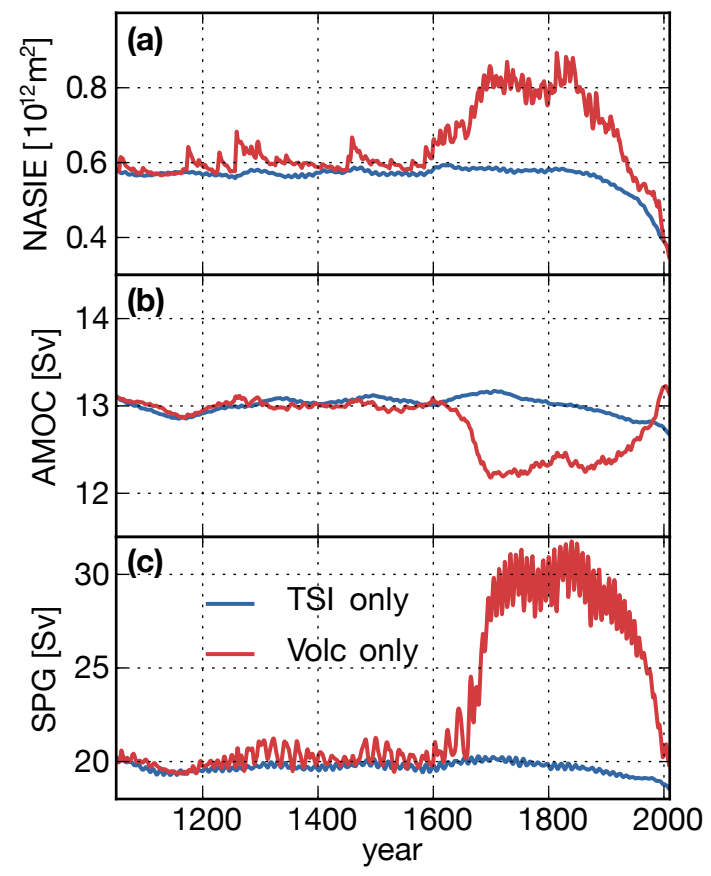

Fig. 4. Last millennium simulations for TSI (blue) and volcanic forcing only (red) without prescribed wind-stress. (a) NASIE, (b) AMOC and (c) SPG.

variability. In contrast to the weak response to TSI forcing, volcanic and wind-stress forcing combined (VOLC, in red) already leads to dynamics very similar to the full forcing case until 1850 (FULL, purple). From this forcing decomposition, we find in accordance with Otterå et al. (2010) and Miller et al. (2012) volcanic forcing to be the dominant driver of pre-industrial North Atlantic variability with both an atmospheric as well as an oceanic response being evident.

In our model simulations, anthropogenic aerosol emissions, which are only incorporated in the FULL case, have a profound impact on the North Atlantic climate system. In TSI and VOLC, the increase in anthropogenic $\mathrm{CO}_{2}$ emissions after 1850 immediately results in a NASIE reduction, SPG weakening and AMOC increase that is greatly delayed in FULL, whereas the NASIE reaches MCA levels in the late 20th century in good agreement with reconstructions (Kinnard et al., 2011). Additionally, we can conclude that profound NASIE reduction leads to SPG weakening in our model simulations.

To support these findings, we conducted the last millennium simulations without prescribed atmospheric variability for TSI and volcanic forcing separately (including anthropogenic $\mathrm{CO}_{2}$ forcing). As shown in Fig. 4, there is little to no variability in the TSI forcing only scenario, whereas in the volcanic forcing only run a sea-ice increase, SPG spinup and AMOC reduction cascade is induced by a series of volcanic eruptions in the early 17 th century. 


\section{Discussion}

The AMOC has been found to be very sensitive to the sea-ice extent in the northern convection region in a variety of climate models (Oka et al., 2012), and it has been proposed by Zhong et al. (2010) that the sea-ice increase due to decadallypaced volcanism might have been the trigger of a persistent AMOC weakening during the LIA. As an initial response to a major volcanic eruption we also find a substantial increase in sea-ice extent in the western Nordic seas, in particular over the Nordic seas convection sites as shown in Fig. 5a. This increase in sea-ice cover reduces ocean heat release and thereby hinders convection in our model. Consequently, overflows over the Greenland-Scotland Ridge are reduced as shown in Fig. 5d, and a cascade of feedbacks leads to a spin-up of the SPG as described above.

Our results suggest that sea-ice increase as a consequence of volcanic eruptions can trigger the SPG regime shift in our model and that this sea-ice forcing has to be persistent in time for longer than the imprint of a single volcanic eruption.

To test this hypothesis we prescribed JFM sea-ice coverage over the northern convection region (Fig. 5a grey box) to be fully covered as after volcanic eruptions in a control run with constant TSI and without prescribed atmospheric variability. As depicted in Fig. 5b, such an abrupt increase in sea ice leads to a reduction in the overflows with a lag of several years, a slowing down of the AMOC and a spinup of the SPG on multi-decadal timescales (solid line). We stopped this artificial sea-ice prescription after $15 \mathrm{yr}$ (dashed line) and found this forcing period to be sufficient to trigger the feedback cascade. Unlike the abrupt strengthening of the SPG in the continuous scenario after $50 \mathrm{yr}$ (Fig. 5e), the SPG spin-up for the $15 \mathrm{yr}$ scenario is more uniform. The persistent increase in sea ice for the continuous scenario leads to an increased sea-ice export to the subpolar North Atlantic that weakens subpolar convection and blocks the SPG spin-up for several decades.

A sea-ice forcing period of $5 \mathrm{yr}$ (Fig. 5 dotted lines) is found to be insufficient to trigger our sea ice-ocean feedbacks and all relevant quantities are found to recover on decadal timescales. Our conceptual experiment therefore supports the suggestion by Zhong et al. (2010) that decadally-paced volcanic forcing can lead to North Atlantic regime shifts that persist on a centennial timescale. However, the dynamic of the SPG in their study of the CCSM3 model are opposite to our findings. They report a weakening of the overflows and the subpolar overturning cell as a reaction to volcanic forcing, the latter induced by increased sea-ice export to the Labrador Sea through the East Greenland Current. In the ensemble average, we find a weak decrease in the annual Nordic seas sea-ice export from $14.2 \mathrm{mSv}$ freshwater equivalent in the 12th century to about $12.1 \mathrm{mSv}$ freshwater equivalent in the 19th century. More importantly, this sea ice is not reaching our subpolar convection site, but is limited to the boundary current. We cannot rule out that this is due
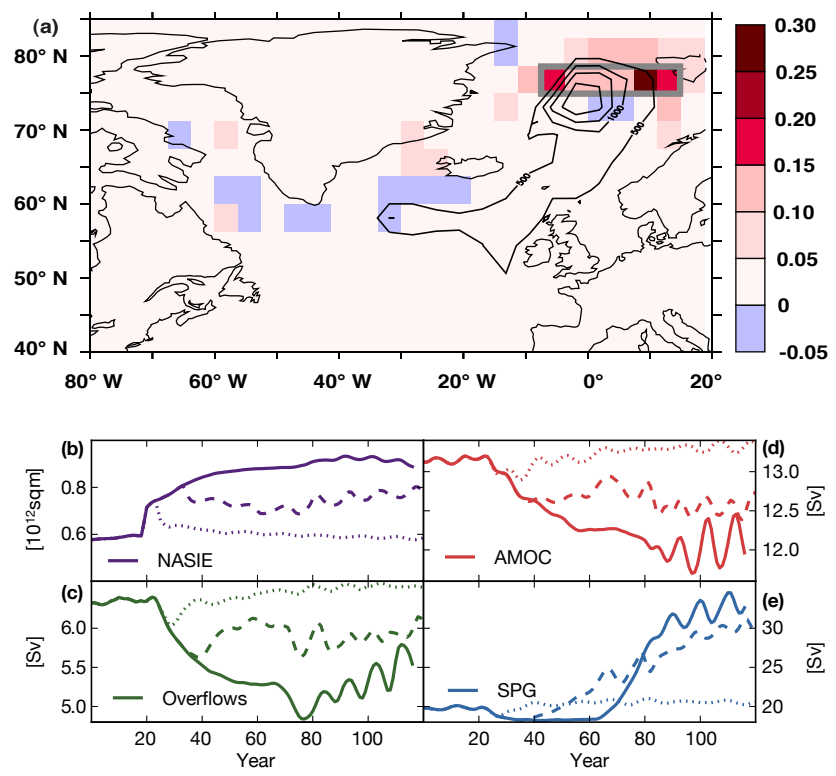

Fig. 5. (a) Difference in annual sea-ice fraction between a decade following a major volcanic eruption (1460-1470) and a reference decade (1440-1450). The sea-ice fraction increase is particularly strong west from Svalbard, which is a key region for deep water formation in our model (February mixed layer depth of the control run overlaid). In a conceptual experiment, the sea-ice extent in this region (grey box) was artificially set to LIA - levels starting from the year 1050. Continuous (straight line), $15 \mathrm{yr}$ (dashed) and $5 \mathrm{yr}$ forcings (dotted) are compared. Constant and $15 \mathrm{yr}$ forcing eventually leads to a rapid increase of NASIE (b), to a reduction in the GSR-overflows (c) and also in the AMOC at $30 \mathrm{~N}$ (d) and to a SPG spin-up (e).

to the displacement of our subpolar convection site from the Labrador Sea to the central Irminger Sea. A recent high resolution model study also reports an anti-correlation of AMOC and SPG dynamics (Zhang et al., 2011b) depending on the strength of the GSR overflows. Observations combined with high-resolution modeling do not indicate a correlation between AMO and SPG over the last 50 yr (Hátún et al., 2009). Model studies of the North Atlantic during the Eemian also highlight the importance of sea-ice dynamics for the AMOC (Born et al., 2009).

\section{Conclusions}

There is a growing body of evidence for the importance of volcanic eruptions as a pacemaker of North Atlantic climate variability on centennial timescales (e.g., Otterå et al., 2010; Mignot et al., 2011; Zhong et al., 2010). Here, we conducted model experiments utilizing reconstructions of atmospheric variability indicating that TSI changes alone cannot explain the pronounced North Atlantic cooling during the LIA. Our findings suggest that volcanic eruptions might have triggered local sea ice-ocean feedbacks that ultimately led to a slowing 
down of the AMOC during the LIA as it is present in multiproxy reconstructions.

As a basis of the stochastic generation of wind-stress field time series applied, we used a reconstruction of the NAO index by Trouet et al. (2009) that shows a distinguished shift from a persistent positive NAO to a more oscillatory regime during the MCA-LIA transition. This characteristic shift is questioned by Lehner et al. (2012) who suggest a more moderate transition. We find the ocean circulation regime shift in our model to be strongly influenced by atmospheric variability regarding the timing but not the nature of the transition that is also found in the absence of prescribed atmospheric variability (compare Fig. 4). This is in good agreement with Palastanga et al. (2011), who report that a persistent negative NAO phase alone is insufficient to explain the LIA in a model study, but that additional AMOC weakening is necessary. In contrast to a basin wide cooling, high resolution sediment records indicate a warming trend in the central subpolar basin SST during the MCA-LIA transition (Miettinen et al., 2012) that is also reproduced by our model (not shown).

However, we want to emphasize that our model of intermediate complexity is of coarse resolution and lacks atmospheric internal variability. Thus, no dynamical atmospheric response to volcanic eruptions is present besides the prescribed stochastically reconstructed time series, which is a clear limitation of our study. Since SPG multi-stability has also been identified in a variety of AOGCMs (Born et al., 2013), it would be interesting to investigate the subpolar circulation dynamics in those models during the MCA-LIA transition in the light of our findings.

We also found our model to be very sensitive to small changes in the Nordic seas freshwater budget and sea-ice extent. This sensitivity might in part be model dependent, but in the light of the major changes in both Arctic freshwater budget (Curry and Mauritzen, 2005) and sea-ice extent (NSIDC, 2012) due to anthropogenic global warming, it raises the question of whether these regional changes might have hemispheric impacts as they presumably had in the past.

Acknowledgements. The authors wish to thank Paola Moffa Sanchez for fruitful discussions and Anders Levermann and two anonymous reviewers for helpful comments and suggestions. This work was supported by the Deutsche Bundesstiftung Umwelt and the German National Academic Foundation.

Edited by: E. Zorita

\section{References}

Born, A., Nisancioglu, K. H., and Braconnot, P.: Sea ice induced changes in ocean circulation during the Eemian, Clim. Dynam. 35, 1361-1371, doi:10.1007/s00382-009-0709-2, 2009.

Born, A., Stocker, T., Raible, C., and Levermann, A.: Is the Atlantic subpolar gyre bistable in comprehensive coupled climate models?, Clim. Dynam., doi:10.1007/s00382-012-1525-7, 40, 29933007, 2013.

Broecker, W.: Was a change in thermohaline circulation responsible for the Little Ice Age?, P. Natl. Acad. Sci., 97, 1339-1342, doi:10.1073/pnas.97.4.1339, 2000.

Büntgen, U., Tegel, W., Nicolussi, K., McCormick, M., Frank, D., Trouet, V., Kaplan, J. O., Herzig, F., Heussner, K.U., and Wanner, H.: 2500 Years of European Climate Variability and Human Susceptibility, Science, 331, 578-582, doi:10.1126/science.1197175, 2011.

Cook, E., D'Arrigo, R., and Mann, M.: A well-verified, multiproxy reconstruction of the winter North Atlantic Oscillation Index since ad 1400*, J. Climate, 15, 1754-1764, 2002.

Crowley, T.: Causes of climate change over the past 1000 years, Science, 289, 270-277, doi:10.1126/science.289.5477.270, 2000.

Curry, R. and Mauritzen, C.: Dilution of the northern North Atlantic Ocean in recent decades, Science, 308, 1772-1774, doi:10.1126/science.1109477, 2005.

de Boyer Montégut, C., Madec, G., Fischer, A., Lazar, A., and Iudicone, D.: Mixed layer depth over the global ocean: An examination of profile data and a profile-based climatology, J. Geophys. Res., 109, C12003, doi:10.1029/2004JC002378, 2004.

Eby, M., Weaver, A. J., Alexander, K., Zickfeld, K., Abe-Ouchi, A., Cimatoribus, A. A., Crespin, E., Drijfhout, S. S., Edwards, N. R., Eliseev, A. V., Feulner, G., Fichefet, T., Forest, C. E., Goosse, H., Holden, P. B., Joos, F., Kawamiya, M., Kicklighter, D., Kienert, H., Matsumoto, K., Mokhov, I. I., Monier, E., Olsen, S. M., Pedersen, J. O. P., Perrette, M., Philippon-Berthier, G., Ridgwell, A., Schlosser, A., Schneider von Deimling, T., Shaffer, G., Smith, R. S., Spahni, R., Sokolov, A. P., Steinacher, M., Tachiiri, K., Tokos, K., Yoshimori, M., Zeng, N., and Zhao, F.: Historical and idealized climate model experiments: an intercomparison of Earth system models of intermediate complexity, Clim. Past, 9, 11111140, doi:10.5194/cp-9-1111-2013, 2013.

Eddy, J.: The maunder minimum, Science, 192, 1189-1202, 1976.

Fernández-Donado, L., González-Rouco, J. F., Raible, C. C., Ammann, C. M., Barriopedro, D., García-Bustamante, E., Jungclaus, J. H., Lorenz, S. J., Luterbacher, J., Phipps, S. J., Servonnat, J., Swingedouw, D., Tett, S. F. B., Wagner, S., Yiou, P., and Zorita, E.: Large-scale temperature response to external forcing in simulations and reconstructions of the last millennium, Clim. Past, 9, 393-421, doi:10.5194/cp-9-393-2013, 2013.

Feulner, G.: Are the most recent estimates for Maunder Minimum solar irradiance in agreement with temperature reconstructions?, Geophys. Res. Lett., 38, L16706, doi:10.1029/2011GL048529, 2011.

Fichefet, T. and Maqueda, M. A. M.: Sensitivity of a global sea ice model to the treatment of ice thermodynamics and dynamics, J. Geophys. Res., 102, 12609-12646, 1997.

Fischer, E. M., Luterbacher, J., Zorita, E., Tett, S. F. B., Casty, C., and Wanner, H.: European climate response to tropical volcanic eruptions over the last half millennium, Geophys. Res. Lett., 34, L05707, doi:10.1029/2006GL027992, 2007. 
Goosse, H., Renssen, H., Timmermann, A., and Bradley, R. S.: Internal and forced climate variability during the last millennium: a model-data comparison using ensemble simulations, Quaternary Sci. Rev., 24, 1345-1360, doi:10.1016/j.quascirev.2004.12.009, 2005.

Goosse, H., Crespin, E., Dubinkina, S., Loutre, M.-F., Mann, M. E., Renssen, H., Sallaz-Damaz, Y., and Shindell, D.: The role of forcing and internal dynamics in explaining the "Medieval Climate Anomaly", Clim. Dynam., 39, 2847-2866, doi:10.1007/s00382-012-1297-0, 2012a.

Goosse, H., Guiot, J., Mann, M. E., Dubinkina, S., and SallazDamaz, Y.: The medieval climate anomaly in Europe: Comparison of the summer and annual mean signals in two reconstructions and in simulations with data assimilation, Global Planet. Change, 84-85, 35-47, doi:10.1016/j.gloplacha.2011.07.002, 2012b.

Gouirand, I., Moberg, A., and Zorita, E.: Climate variability in Scandinavia for the past millennium simulated by an atmosphere-ocean general circulation model, Tellus A, 59, 3049, doi:10.1111/j.1600-0870.2006.00207.x, 2006.

Gray, L. J., Beer, J., Geller, M., Haigh, J. D., Lockwood, M., Matthes, K., Cubasch, U., Fleitmann, D., Harrison, G., Hood, L., Luterbacher, J., Meehl, G. A., Shindell, D., Geel, B. V., and White, W.: Solar influences on climate, Rev. Geophys., 48, RG4001, doi:10.1029/2009RG000282, 2010.

Gregory, J. M., Dixon, K. W., Stouffer, R. J., Weaver, A. J., Driesschaert, E., Eby, M., Fichefet, T., Hasumi, H., Hu, A., Jungclaus, J. H., Kamenkovich, I. V., Levermann, A., Montoya, M., Murakami, S., Nawrath, S., Oka, A., Sokolov, A. P., and Thorpe, R. B.: A model intercomparison of changes in the Atlantic thermohaline circulation in response to increasing atmospheric $\mathrm{CO}_{2}$ concentration, Geophys. Res. Lett., 32, L12703, doi:10.1029/2005GL023209, 2005.

Hátún, H., Payne, M., Beaugrand, G., Reid, P., Sand $\varnothing$, A., Drange, H., Hansen, B., Jacobsen, J., and Bloch, D.: Large bio-geographical shifts in the north-eastern Atlantic Ocean: From the subpolar gyre, via plankton, to blue whiting and pilot whales, Prog. Oceanogr., 80, 149-162, doi:10.1016/j.pocean.2009.03.001, 2009.

Hofer, D., Raible, C. C., and Stocker, T. F.: Variations of the Atlantic meridional overturning circulation in control and transient simulations of the last millennium, Clim. Past, 7, 133-150, doi:10.5194/cp-7-133-2011, 2011.

Hunt, B. G.: The Medieval Warm Period, the Little Ice Age and simulated climatic variability, Clim. Dynam., 27, 677-694, doi:10.1007/s00382-006-0153-5, 2006.

Hunt, B. G.: Wind forcing of the ocean and the Atlantic meridional overturning circulation, Clim. Dynam., 37, 19-34, doi:10.1007/s00382-010-0860-9, 2011.

Hurrel, J.: NAO Index Data provided by the Climate Analysis Section, NCAR, Boulder, USA, Updated regularly, http://climatedataguide.ucar.edu/guidance/ hurrell-north-atlantic-oscillation-nao-index-pc-based, last access: 20 May 2012.

Hurrell, J. and Deser, C.: North Atlantic climate variability: the role of the North Atlantic Oscillation, J. Mar. Syst., 78, 28-41, doi:10.1016/j.jmarsys.2008.11.026, 2009.
Jansen, E., Overpeck, J., Briffa, K. R., Duplessy, J.-C., Joos, F., Masson-Delmotte, V., Olago, D., Otto-Bliesner, B., Peltier, W. R., Rahmstorf, S., Ramesh, R., Raynaud, D., Rind, D., Solomina, O., Villalba, R., and Zhang, D.: Palaeoclimate, Climate Change 2007: The Physical Science Basis, Contribution of Working Group I to the Fourth Assessment Report of the Intergovernmental Panel on Climate Change, Chapter 6, edited by: Solomon, S., Qin, D., Manning, M., Chen, Z., Marquis, M., Averyt, K. B., Tignor, M., and Miller, H. L., Cambridge University Press, Cambridge, UK and New York, NY, USA, 443-498, 2007.

Jones, P. and Mann, M.: Climate over past millennia, Rev. Geophys., 42, RG2002, doi:10.1029/2003RG000143, 2004.

Kalnay, E., Kanamitsu, M., Kistler, R., Collins, W., Deaven, D., Gandin, L., Iredell, M., Saha, S., White, G., Woollen, J., Zhu, Y., Leetmaa, A., Reynolds, B., Chelliah, M., Ebisuzaki, W., Higgins, W., Janowiak, J., Mo, K. C., Ropelewski, C., Wang, J., Jenne, R., and Joseph, D.: The NCEP/NCAR 40-year reanalysis project, B. Am. Meteorol. Soc., 77, 437-471, 1996.

Kinnard, C., Zdanowicz, C. M., Fisher, D. A., Isaksson, E., de Vernal, A., and Thompson, L. G.: Reconstructed changes in Arctic sea ice over the past 1,450 years, Nature, 479, 509-512, doi:10.1038/nature10581, 2011.

Kirchner, I., Stenchikov, G. L., Graf, H.-F., Robock, A., and Antua, J. C.: Climate model simulation of winter warming and summer cooling following the 1991 Mount Pinatubo volcanic eruption, J. Geophys. Res.-Atmos., 104, 19039-19055, doi:10.1029/1999JD900213, 1999.

Knight, J. R., Allen, R. J., Folland, C. K., Vellinga, M., and Mann, M. E.: A signature of persistent natural thermohaline circulation cycles in observed climate, Geophys. Res. Lett., 32, L20708, doi:10.1029/2005GL024233, 2005.

Knudsen, M. F., Seidenkrantz, M.-S., Jacobsen, B. H., and Kuijpers, A.: Tracking the Atlantic Multidecadal Oscillation through the last 8,000 years, Nat. Commun., 2, 178, doi:10.1038/ncomms1186, 2011.

Kopp, G. and Lean, J.: A new, lower value of total solar irradiance: evidence and climate significance, Geophys. Res. Lett., 38, L01706, doi:10.1029/2010GL045777, 2011.

Kuhlbrodt, T., Griesel, A., Montoya, M., Levermann, A., Hofmann, M., and Rahmstorf, S.: On the driving processes of the Atlantic meridional overturning circulation, Rev. Geophys., 45, RG2001, doi:10.1029/2004RG000166, 2007.

Lehner, F., Raible, C. C., and Stocker, T. F.: Testing the robustness of a precipitation proxy-based North Atlantic Oscillation reconstruction, Quaternary Sci. Rev., 45, 85-94, doi:10.1016/j.quascirev.2012.04.025, 2012.

Levermann, A. and Born, A.: Bistability of the subpolar gyre in a coarse resolution climate model, Geophys. Res. Lett., 34, L24605, doi:10.1029/2007GL031732, 2007.

Lund, D., Lynch-Stieglitz, J., and Curry, W.: Gulf Stream density structure and transport during the past millennium, Nature, 444, 601-604, doi:10.1038/nature05277, 2006.

Luterbacher, J., Xoplaki, E., Dietrich, D., Rickli, R., Jacobeit, J., Beck, C., Gyalistras, D., Schmutz, C., and Wanner, H.: Reconstruction of sea level pressure fields over the Eastern North Atlantic and Europe back to 1500, Clim. Dynam., 18, 545-561, doi:10.1007/s00382-001-0196-6, 2002. 
Macias Fauria, M., Grinsted, A., Helama, S., Moore, J., Timonen, M., Martma, T., Isaksson, E., and Eronen, M.: Unprecedented low twentieth century winter sea ice extent in the Western Nordic Seas since A.D. 1200, Clim. Dynam., 34, 781-795, doi:10.1007/s00382-009-0610-z, 2009.

Mann, M. E., Zhang, Z., Rutherford, S., Bradley, R. S., Hughes, M. K., Shindell, D., Ammann, C., Faluvegi, G., and Ni, F.: Global signatures and dynamical origins of the Little Ice Age and Medieval Climate Anomaly., Science, 326, 1256-1260, doi:10.1126/science.1177303, 2009.

Menary, M. B., Park, W., Lohmann, K., Vellinga, M., Palmer, M. D., Latif, M., and Jungclaus, J. H.: A multimodel comparison of centennial Atlantic meridional overturning circulation variability, Clim. Dynam., 38, 2377-2388, doi:10.1007/s00382-011-1172-4, 2011.

Mengel, M., Levermann, A., Schleussner, C.-F., and Born, A.: Enhanced Atlantic subpolar gyre variability through baroclinic threshold in a coarse resolution model, Earth Syst. Dynam., 3, 189-197, doi:10.5194/esd-3-189-2012, 2012.

Miettinen, A., Divine, D., Koç, N., Godtliebsen, F., and Hall, I. R.: Multicentennial Variability of the Sea Surface Temperature Gradient across the Subpolar North Atlantic over the Last $2.8 \mathrm{kyr}, \mathrm{J}$. Climate, 25, 4205-4219, doi:10.1175/JCLI-D-11-00581.1, 2012.

Mignot, J., Khodri, M., Frankignoul, C., and Servonnat, J.: Volcanic impact on the Atlantic Ocean over the last millennium, Clim. Past, 7, 1439-1455, doi:10.5194/cp-7-1439-2011, 2011.

Miller, G. H., Geirsdóttir, A., Zhong, Y., Larsen, D. J., Otto, B. L., Holland, M. M., Bailey, D. A., Refsnider, K. A., Lehman, S. J., and John, R.: Abrupt onset of the Little Ice Age triggered by volcanism and sustained by sea-ice / ocean feedbacks, Geophys. Res. Lett, 39, L02708, doi:10.1029/2011GL050168, 2012.

Montoya, M., Griesel, A., Levermann, A., Mignot, J., Hofmann, M., Ganopolski, A., and Rahmstorf, S.: The Earth System Model of Intermediate Complexity CLIMBER-3 $\alpha$, Part I: description and performance for present day conditions, Clim. Dynam., 25, 237263, 2005.

Msadek, R. and Frankignoul, C.: Atlantic multidecadal oceanic variability and its influence on the atmosphere in a climate model, Clim. Dynam., 33, 45-62, doi:10.1007/s00382-0080452-0, 2009.

NSIDC: The National Snow and Ice Data Center University of Colorado, Boulder, http://www.nsidc.org/, last access: 14 October 2012 .

Oka, A., Hasumi, H., and Abe-Ouchi, A.: The thermal threshold of the Atlantic meridional overturning circulation and its control by wind stress forcing during glacial climate, Geophys. Res. Lett., 39, L09709, doi:10.1029/2012GL051421, 2012.

Olsen, J., Anderson, N. J., and Knudsen, M. F.: Variability of the North Atlantic Oscillation over the past 5,200 years, Nat. Geosci., 5, 808-812, doi:10.1038/ngeo1589, 2012.

Ortega, P., Montoya, M., González-Rouco, F., Mignot, J., and Legutke, S.: Variability of the Atlantic meridional overturning circulation in the last millennium and two IPCC scenarios, Clim. Dynam., 38, 1925-1947, doi:10.1007/s00382-011-1081-6, 2011.

Otterå, O., Bentsen, M., Drange, H., and Suo, L.: External forcing as a metronome for Atlantic multidecadal variability, Nat. Geosci., 3, 688-694, doi:10.1038/ngeo955, 2010.
Pacanowski, R. C. and Griffies, S. M.: The MOM-3 manual, Tech. Rep. 4, NOAA/Geophyical Fluid Dynamics Laboratory, Princeton, NJ, USA, 1999.

Palastanga, V., Van der Schrier, G., Weber, S., Kleinen, T., Briffa, K., and Osborn, T.: Atmosphere and ocean dynamics : contributors to the European Little Ice Age?, Clim. Dynam., 36, 973-987, doi:10.1007/s00382-010-0751-0, 2011.

Park, W. and Latif, M.: Atlantic Meridional Overturning Circulation response to idealized external forcing, Clim. Dynam., 39, 17091726, doi:10.1007/s00382-011-1212-0, 2011.

Parker, D., Folland, C., Scaife, A., Knight, J., Colman, A., Baines, P., and Dong, B.: Decadal to multidecadal variability and the climate change background, J. Geophys. Res., 112, D18115, doi:10.1029/2007JD008411, 2007.

Petoukhov, V., Ganopolski, A., Brovkin, V., Claussen, M., Eliseev, A., Kubatzki, C., and Rahmstorf, S.: CLIMBER-2: a climate system model of intermediate complexity, Part I: model description and performance for present climate, Clim. Dynam., 16, 1-17, doi:10.1007/PL00007919, 2000.

Pohlmann, H., Jungclaus, J. H., Köhl, A., Stammer, D., and Marotzke, J.: Initializing Decadal Climate Predictions with the GECCO Oceanic Synthesis: Effects on the North Atlantic, J. Climate, 22, 3926-3938, doi:10.1175/2009JCLI2535.1, 2009.

Robock, A.: The "Little Ice Age": Northern Hemisphere Average Observations and Model Calculations, Science, 206, 1402-1404, 1979.

Robock, A.: Volcanic eruptions and climate, Rev. Geophys., 38, 191-219, doi:10.1029/1998RG000054, 2000.

Schlesinger, M. and Ramankutty, N.: An oscillation in the global climate system of period 65-70 years, Nature, 367, 723-726, doi:10.1038/367723a0, 1994.

Schmidt, G. A., Jungclaus, J. H., Ammann, C. M., Bard, E., Braconnot, P., Crowley, T. J., Delaygue, G., Joos, F., Krivova, N. A., Muscheler, R., Otto-Bliesner, B. L., Pongratz, J., Shindell, D. T., Solanki, S. K., Steinhilber, F., and Vieira, L. E. A.: Climate forcing reconstructions for use in PMIP simulations of the last millennium (v1.0), Geosci. Model Dev., 4, 33-45, doi:10.5194/gmd4-33-2011, 2011.

Schulz, M., Prange, M., and Klocker, A.: Low-frequency oscillations of the Atlantic Ocean meridional overturning circulation in a coupled climate model, Clim. Past, 3, 97-107, doi:10.5194/cp3-97-2007, 2007.

Sedláček, J. and Mysak, L. A.: Sensitivity of sea ice to windstress and radiative forcing since 1500: a model study of the Little Ice Age and beyond, Clim. Dynam., 32, 817-831, doi:10.1007/s00382-008-0406-6, 2009.

Shindell, D. T.: Dynamic winter climate response to large tropical volcanic eruptions since 1600, J. Geophys. Res., 109, D05104, doi:10.1029/2003JD004151, 2004.

Steinhilber, F., Beer, J., and Fröhlich, C.: Total solar irradiance during the Holocene, Geophys. Res. Lett., 36, L19704, doi:10.1029/2009GL040142, 2009.

Stenchikov, G. L., Kirchner, I., Robock, A., Graf, H.-F., Antuña, J. C., Grainger, R. G., Lambert, A., and Thomason, L.: Radiative forcing from the 1991 Mount Pinatubo volcanic eruption, J. Geophys. Res., 103, 13837, doi:10.1029/98JD00693, 1998. 
Stouffer, R. J., Yin, J., Gregory, J. M., Dixon, K. W., Spelman, M. J., Hurlin, W., Weaver, A. J., Eby, M., Flato, G. M., Hasumi, H., Hu, A., Jungclaus, J. H., Kamenkovich, I. V., Levermann, A., Montoya, M., Murakami, S., Nawrath, S., Oka, A., Peltier, W. R., Robitaille, D. Y., Sokolov, A. P., Vettoretti, G., and Weber, S. L.: Investigating the Causes of the Response of the Thermohaline Circulation to Past and Future Climate Changes, J. Climate, 19, 1365-1387, doi:10.1175/JCLI3689.1, 2006.

Swingedouw, D., Terray, L., Servonnat, J., and Guiot, J.: Mechanisms for European summer temperature response to solar forcing over the last millennium, Clim. Past, 8, 1487-1495, doi:10.5194/cp-8-1487-2012, 2012.

Timmreck, C.: Modeling the climatic effects of large explosive volcanic eruptions, Wiley Interdisciplinary Reviews: Climate Change, 3, 545-564, doi:10.1002/wcc.192, 2012.

Trenberth, K., Olson, J., and Large, W.: A Global Ocean Wind Stress Climatology based on ECMWF Analysis, Tech. Rep. NCAR/TN-338+STR, National Center for Atmospheric Research, Boulder, Colorado, USA, 1989.

Trouet, V., Esper, J., Graham, N. E., Baker, A., Scourse, J. D., and Frank, D. C.: Persistent positive North Atlantic oscillation mode dominated the Medieval Climate Anomaly, Science, 324, 78-80, doi:10.1126/science.1166349, 2009.

Wang, Y., Lean, J., and Sheeley Jr, N.: Modeling the sun's magnetic field and irradiance since 1713, Astrophys. J., 625, 522, doi:10.1086/429689, 2008.
Zanchettin, D., Timmreck, C., Graf, H.-F., Rubino, A., Lorenz, S., Lohmann, K., Krüger, K., and Jungclaus, J. H.: Bi-decadal variability excited in the coupled ocean-atmosphere system by strong tropical volcanic eruptions, Clim. Dynam., 39, 419-444, doi:10.1007/s00382-011-1167-1, 2011.

Zhang, D. D., Lee, H. F., Wang, C., Li, B., Pei, Q., Zhang, J., and An, Y.: The causality analysis of climate change and largescale human crisis, P. Natl. Acad. Sci., 108, 17296-17301, doi:10.1073/pnas.1104268108, 2011a.

Zhang, R., Delworth, T., Rosati, A., Anderson, W., Dixon, K., Lee, H., and Zeng, F.: Sensitivity of the North Atlantic Ocean Circulation to an abrupt change in the Nordic Sea overflow in a high resolution global coupled climate model, J. Geophys. Res., 116, C12024, doi:10.1029/2011JC007240, 2011b.

Zhong, Y., Miller, G. H., Otto-Bliesner, B. L., Holland, M. M., Bailey, D. A., Schneider, D. P., Geirsdottir, A., and Dyn, C.: Centennial-scale climate change from decadally-paced explosive volcanism: a coupled sea ice-ocean mechanism, Clim. Dynam., 37, 2373-2387, doi:10.1007/s00382-010-0967-z, 2010.

Zorita, E., von Storch, H., Gonzalez-Rouco, F. J., Cubasch, U., Luterbacher, J., Legutke, S., Fischer-Bruns, I., and Schlese, U.: Climate evolution in the last five centuries simulated by an atmosphere-ocean model: global temperatures, the North Atlantic Oscillation and the Late Maunder Minimum, Meteorol. Z., 13, 271-289, doi:10.1127/0941-2948/2004/0013-0271, 2004. 